\title{
PROBLEMY METODOLOGICZNE W ZARZĄDZANIU PROJEKTAMI Z ZAKRESU OCENY TECHNOLOGII
}

\begin{abstract}
W artykule omówiono główne problemy metodologiczne związane z realizacją ekspertyz z zakresu oceny technologii. Ocena technologii (Technology Assessment) jest wewnętrznie zróżnicowaną dziedziną badań problemowych znajdującą się na styku nauki, polityki, technologii i społeczeństwa, gdzie na podstawie aktualnej wiedzy rozproszonej w różnych dyscyplinach naukowych próbuje się rozpoznawać możliwe ścieżki rozwoju technologicznego, przewidywać przyszłe skutki wyboru konkretnych ścieżek dla jednostki i społeczeństwa, dla gospodarki i środowiska, dla bezpieczeństwa narodowego i pozycji państwa w globalnym wyścigu technologicznym oraz poddawać te możliwości ocenie pod kątem wartości akceptowanych przez społeczeństwo. Zarządzanie projektami badawczymi o takich aspiracjach wymaga rozległych kompetencji metodologicznych. Składający się z czterech części artykuł jest adresowany do czytelników posiadających podstawową wiedzę w zakresie teorii nauki i ogólnej metodologii nauk. W części pierwszej omówiono istotę oceny technologii i jej znaczenie dla nowoczesnej polityki technologicznej i innowacyjnej. Druga zawiera ogólną charakterystykę metodologiczną oceny technologii jako interdyscyplinarnych i transdyscyplinarnych badań nad uwarunkowaniami i skutkami rozwoju i upowszechniania technologii. W trzeciej części zaprezentowano najpopularniejsze metody i procedury znajdujące zastosowanie w projektach z zakresu oceny technologii. Katalog metod usystematyzowanych według celu zawiera metody strukturalizujące, metody pozyskiwania danych, metody heurystyczne, metody prognostyczne i metody ewaluacyjne. Typologia bazująca na kryterium pochodzenia metod wyróżnia: metody zorientowane technologicznie, metody wywodzące się z ekonomii, metody zorientowane politycznie, systematyczne metody bilansowe i metody wywodzące się z tradycji teorii systemów i analizy systemowej. W części czwartej autor określa główne wymogi jakościowe stawiane ekspertyzom z tego obszaru. Punkt wyjścia omówienia stanowi klasyczna koncepcja oceny technologii realizowana przez Biuro Oceny Technologii przy Kongresie Stanów Zjednoczonych w latach 1972-1995. W podsumowaniu zaproponowano uniwersalny model proceduralny oceny technologii stanowiący kombinację kilku wypróbowanych metod.

Słowa kluczowe: zarządzanie projektami, ocena technologii, ocena skutków, metodologia nauk, naukowe doradztwo polityczne, standardy jakościowe ekspertyzy
\end{abstract}

\section{WPROWADZENIE}

W warunkach wzrastającego gospodarczego i politycznego znaczenia technologii oraz nasilającego się międzynarodowego współzawodnictwa w dziedzinie rozwoju naukowotechnologicznego niewiele krajów może sobie obecnie pozwolić na rezygnację z aktywnej polityki technologicznej. Trudno sobie jednak wyobrazić racjonalną politykę technologiczną bez właściwej oceny aktualnej sytuacji kraju czy regionu pod kątem posiadanych zasobów, społecznych potrzeb i możliwości ich zaspokojenia poprzez odpowiednie ukierunkowanie rozwoju naukowo-technologicznego. Od umiejętności prawidłowego, czyli

\footnotetext{
Krzysztof Michalski, dr, Zakład Nauk Humanistycznych, Wydział Zarządzania, Politechnika Rzeszowska, Al. Powstańców Warszawy 12, 35-959 Rzeszów, tel.: (17) 86512 04, e-mail: michals@prz.edu.pl
} 
odpowiednio wczesnego i trafnego rozpoznania szans i zagrożeń związanych z rozwojem i upowszechnianiem określonych technologii, zależy nie tylko powodzenie szeroko rozumianej polityki gospodarczej, ale w dużej mierze także powodzenie wielu innych polityk sektorowych, takich jak na przykład polityka bezpieczeństwa, polityka społeczna czy polityka środowiskowa.

Świadomość rosnącego znaczenia właściwego rozpoznania technologicznego dla gospodarki i dobrobytu obywateli oraz dla prawidłowego (zgodnego z międzynarodowymi standardami) funkcjonowania organów państwa skłania obecnie wiele krajów do wykorzystywania posiadanych zasobów informacyjnych i kompetencyjnych do budowy rozległego systemu doradztwa na potrzeby bieżącej, a także długoterminowej polityki technologicznej. Zarówno w większości krajów, jak i na płaszczyźnie międzynarodowej dominuje „klasyczny” model organizacyjny takiego doradztwa. Zakłada on kluczową rolę organów ustawodawczych w procesie kształtowania technologii. Również na obszarze legislatywy identyfikuje największą potrzebę zaopatrzenia w miarodajną i wiarygodną naukową opinię o szansach i zagrożeniach dla jednostki i społeczeństwa związanych z możliwymi scenariuszami technologicznymi.

Proces budowy takiego nowoczesnego parlamentarnego doradztwa na potrzeby polityki technologicznej został zapoczątkowany na przełomie lat sześćdziesiątych i siedemdziesiątych XX w. w Stanach Zjednoczonych w warunkach wojny technologicznej między Wschodem a Zachodem, której symbolem był podbój kosmosu. Wczesne rozpoznanie szans i zagrożeń wynikających z rozwoju i upowszechniania technologii oraz szacowanie skutków odnośnych działań legislacyjnych prowadzone przez prawie 25 lat (do 1995 r.) pod wspólną nazwą Technology Assessment (TA) w coraz bardziej systematyczny sposób, na coraz rozleglejszych płaszczyznach i na coraz większą skalę przyczyniły się znacząco nie tylko do racjonalizacji i optymalizacji polityki technologicznej Stanów Zjednoczonych, ale także do odbudowy społecznego zaufania do instytucji publicznych i procesów politycznych, nadszarpniętego przez skandale korupcyjne i defraudacyjne ujawniane w mediach oraz przez codzienny natarczywy lobbing wielkiego przemysłu. Wielopłaszczyznowe korzyści wynikające $\mathrm{z}$ funkcjonowania systemu profesjonalnego doradztwa na potrzeby polityki technologicznej zarówno dla amerykańskiego społeczeństwa, biznesu, jak i dla samych aktorów politycznych zostały dostrzeżone również przez inne kraje. W połowie lat dziewięćdziesiątych XX w. liderzy światowego wyścigu technologicznego (głównie Niemcy, Japonia, Francja i Wielka Brytania), a z czasem także państwa o mniejszym znaczeniu ,technopolitycznym”, zbudowały analogiczne struktury kompetencyjne ukierunkowane na działalność opiniodawczą i konsultacyjną na potrzeby procesu legislacyjnego.

Geneza oceny technologii nie była więc pierwotnie związana z naukową potrzebą wyjaśnienia warunków rozwoju naukowo-technologicznego i problemów sterowania procesem upowszechniania technologii. Ocena technologii powstała bardziej „na zamówienie polityczne" niż pod wpływem odkrycia naukowej doniosłości problemu. Nie jest więc ona nową ofertą nauki adresowaną do polityki, lecz pomysłem samych polityków². Jednak w związku z prężnym rozwojem „,rynku zamówień” w krajach, w których ocena technologii została społecznie ,zakontraktowana”, środowiska akademickie z coraz większą

\footnotetext{
${ }^{2}$ F. Gloede, Rationalisierung oder reflexive Verwissenschaftlichung? Zur Debatte um die Funktionen von Technikfolgen-Abschätzung für Technikpolitik [w:] Technikfolgen-Abschätzung als Technikforschung und Politikberatung, red. Th. Petermann, Frankfurt am Main 1991, s. 301.
} 
uwagą śledzą rozwój tej nowej gałęzi nauk stosowanych i coraz chętniej angażują się w działalność ekspercką na obszarze oceny technologii.

Tematyka podejmowana w niniejszym artykule jest w Polsce mało znana ze względu na niewielkie dotychczas zainteresowanie oceną technologii zarówno ze strony świata polityki, jak i ze strony środowisk naukowych. Rozwój oceny technologii w Polsce utrudniły procesy transformacyjne ostatnich 25 lat, szczególnie restrukturyzacje w sektorze przemysłu oraz zbyt powolne kształtowanie się społeczeństwa obywatelskiego. Krajowy rynek zamówień na całościowe ekspertyzy z zakresu TA w zasadzie nie istnieje. Polska jest obecnie jednym z sześciu krajów członkowskich Unii Europejskiej (UE), które nie mają na poziomie parlamentu wyodrębnionych struktur doradczych specjalizujących się w ocenie technologii. Próby zbudowania takich kompetencji na wzór rozwiązań zachodnioeuropejskich podejmuje od niedawna Biuro Analiz Sejmowych działające przy Kancelarii Sejmu RP. Zauważalne są także oddolne inicjatywy polskich środowisk naukowych skupionych wokół idei oceny technologii, czego wyrazem są: powstanie w 2013 r. Polskiej Akademickiej Sieci Oceny Technologii (PANTA, Polish Academic Network of Technology Assessment) oraz rejestracja w bieżącym roku Polskiego Towarzystwa Oceny Technologii (PTOT). W tej sytuacji można się spodziewać, że w najbliższej przyszłości pod wpływem polityki spójności UE ocena technologii stanie się w Polsce dynamicznie rozwijającym się rynkiem zamówień dla nauki oraz ważnym obszarem interakcyjnym leżącym na styku polityki, nauki, biznesu i społeczeństwa obywatelskiego.

Zbudowanie w Polsce odpowiednich kompetencji po stronie nauki wymaga upowszechnienia podstawowej wiedzy o teorii i praktyce oceny technologii, doświadczeniach w realizacji projektów z tego obszaru w innych krajach, ale przede wszystkich o problemach metodologicznych towarzyszących zarządzaniu takimi złożonymi pod względem strukturalnym i funkcjonalnym projektami badawczo-konsultacyjnymi. Ponieważ ocena technologii jest dla nauki „nowym lądem” i „ziemią niczyją”, różne dyscypliny próbują postawić swoją stopę na tym nowym lądzie i obszar ten „skolonizować”, wprowadzając tam własną kulturę naukową. Temu procesowi „kolonizacji” od początku z konieczności towarzyszą spory metodologiczne o właściwy dobór metod badawczych, adekwatność poszczególnych metod i wartość uzyskanych z ich pomocą rezultatów. Dlatego też na przestrzeni 40 lat rozwoju ocena technologii funkcjonowała jako metodologicznie interesujący obszar doświadczalny, swoiste laboratorium, w którym wypróbowywano tysiące receptur naukowych, wykorzystujących dziesiątki metod w coraz to nowych konfiguracjach. Realizując ekspertyzy zorientowane na konkretne problemy, spierano się jednocześnie o prawomocność prowadzonych przy tej okazji metodologicznych eksperymentów.

Na podstawie zgromadzonego rozległego materiału doświadczalnego z dotychczasowej praktyki badawczej można wyodrębnić pewne często spotykane problemy i ich typowe sposoby rozwiązywania związane z metodyką pracy badawczej specyficznej dla projektów z zakresu oceny technologii. Prowadzone w ramach międzynarodowego projektu badawczego „InvenTA” od trzech lat badania, których wyniki prezentuje niniejszy artykuł, miały na celu identyfikację kluczowych problemów metodologicznych towarzyszących realizacji projektów badawczych z obszaru oceny technologii. Ze względu na omówioną $\mathrm{w}$ dalszej części artykułu specyfikę oceny technologii, zarządzanie projektami z tego obszaru wymaga wysokiej kultury metodologicznej: samokontroli, rozumienia specyfiki problemów, świadomości ograniczeń oraz umiejętności doboru i właściwego korzystania z nowoczesnych narzędzi dostarczanych przez nauki szczegółowe. 


\section{OGÓLNA CHARAKTERYSTYKA METODOLOGICZNA OCENY TECHNOLOGII}

Obszar oceny technologii jako badań problemowych odpowiadających nowemu paradygmatowi Mode-2-Science cechuje taka wielość podejść, że charakterystyka projektów w tradycyjnych kategoriach przedmiotu, aspektu, metody i celu jest nieadekwatna. Zamiast tego należy ogólnie charakteryzować metodologiczny profil oceny technologii, najlepiej wychodząc od pierwotnej, klasycznej koncepcji oceny technologii realizowanej przez Office of Technology Assessment (OTA) - działającą od 1972 r. przy Kongresie Stanów Zjednoczonych pierwszą i przez prawie 20 lat jedyną na świecie instytucję specjalizującą się w realizacji takich projektów.

Klasyczny amerykański program postawił doradztwu naukowemu w kwestiach polityki technologicznej za cel między innymi:

- $\quad$ problemowe, tematyczne integrowanie wiedzy dostępnej w różnych dziedzinach nauki i dostarczenie jej w przystępnej formie opinii publicznej i decydentom politycznym;

- możliwie wczesne rozpoznanie skutków upowszechniania technologii dla indywidualnych i zbiorowych interesariuszy oraz wczesne ostrzeganie przed zagrożeniami związanymi z rozwojem danej technologii;

- $\quad$ ocenę tych skutków i poszczególnych opcji decyzyjnych pod kątem społecznej akceptowalności;

- rozwiązanie problemów metodologicznych wyłaniających się w kontekście poprzednich zadań zarówno na płaszczyźnie identyfikacji skutków (problemy kognitywne), jak i na płaszczyźnie ich oceny (problemy normatywne).

W przeciwieństwie do stronniczych lobbystycznych ocen przemysłu lub politycznych grup nacisku ocena technologii ma doradzać decydentom politycznym zgodnie z zasadami naukowej bezstronności. Zalety oceny technologii na tle dotychczasowego, zdezintegrowanego dyscyplinarnego doradztwa naukowego upatrywano między innymi w:

- większej całościowości, kompletności (komprehensywności) i integralności analiz umożliwiających rozległe interdyscyplinarne uchwycenie sprzężeń i współzależności dotychczas nietematyzowanych;

- odpowiednio wczesnym ostrzeganiu przed problemami dostrzeganymi dotychczas zbyt późno (związanymi z wtórnymi i tercjarnymi, synergicznymi, kaskadowymi, kumulatywnymi i rykoszetowymi efektami rozwoju technologicznego występującymi z opóźnieniem);

- $\quad$ społecznie transparentnej, porównawczej ocenie alternatywnych wariantów rozwoju, przeprowadzanej często na zasadach partycypacji, a więc przy udziale laików: interesariuszy lub osób postronnych. Angażowanie obywateli w publiczne procesy decyzyjne ma zapewnić większą wiarygodność i społeczną legitymację decyzjom politycznym, budzącym nierzadko społeczne kontrowersje, a w skrajnych sytuacjach prowadzącym do ostrych konfliktów interesów $w^{3}$.

Należy zastrzec, że koncepcja klasyczna to metodologiczna idealizacja, w rzeczywistości nigdy i nigdzie ocena technologii nie była praktykowana $\mathrm{w}$ takiej formie, ponieważ- ściśle biorąc - koncepcja jest pragmatycznie niewykonalna. Po 40 latach doświad-

\footnotetext{
${ }^{3}$ Ibidem, s. 303.
} 
czeń klasyczna amerykańska koncepcja okazała się utopijnym programem naukowej produkcji wiedzy na potrzeby praktyki politycznej, którego nie było w stanie faktycznie zrealizować żadne znane opracowanie. Najistotniejsze postulaty „klasycznego” programu oceny technologii, które pozwalają zrozumieć powody jego późniejszej krytyki i zdystansowania się do niego, to:

- aksjonormatywna, światopoglądowa neutralność;

- podporządkowanie celom polityczno-doradczym;

- $\quad$ systemowy charakter;

- $\quad$ ekspercki (nie ekspertokratyczny) model i interdyscyplinarny profil;

- $\quad$ orientacja prognostyczna: badania o charakterze przeddecyzyjnym ${ }^{4}$.

Postulaty te wynikają z następujących założeń metodologicznych przyjętych w koncepcji klasycznej:

1) założenie o aksjonormatywnej neutralności oceny technologii i wynikającym z niego decyzjonistycznym podziale zadań między naukę a politykę. Propagowany program badawczy przydziela nauce zadanie dostarczania wyłącznie wiedzy opisowej w postaci wykazu opcji decyzyjnych scharakteryzowanych pod kątem skutków oczekiwanych realnie lub hipotetycznie (tzn. z obliczalnym lub nieobliczalnym prawdopodobieństwem wystąpienia), natomiast zadania normatywne pozostają w kompetencji systemu politycznego. Według koncepcji klasycznej zadania nauki sprowadzają się do szacowania skutków rozwoju i upowszechniania określonej technologii, którego rezultatem nie mają być konkretne zalecenia i rekomendacje dotyczące wyboru najlepszych możliwości, a tylko informacje, jakie w ogóle są możliwości działania i z jakimi konsekwencjami trzeba się liczyć w razie wyboru jednej z nich. Eksperci mają ustalić wszystkie dostępne alternatywy i zestawić argumenty ,za” i ,przeciw” w odniesieniu do każdej z nich. Ustalanie priorytetów i preferencji oraz wybór na ich podstawie „właściwego” wariantu działania pozostają w gestii decydentów politycznych;

2) założenie o centralnej sterującej roli państwa w dziedzinie rozwoju naukowotechnologicznego. Tylko państwo jest w stanie w centralnym miejscu gromadzić wiedzę niezbędną do właściwego ukierunkowania rozwoju technologicznego, tylko państwo dzięki strukturom demokratycznym reprezentuje preferencje, interesy i wolę obywateli i tylko państwo dysponuje narzędziami pozwalającymi realizować „wolę społeczną" w odniesieniu do rozwoju naukowo-technologicznego;

3) założenie, że z naukowego punktu widzenia możliwa jest pełna (komprehensywna) i wiarygodna (spolegliwa) ilościowa inwentaryzacja i analiza skutków technologii dzięki właściwemu doborowi i zastosowaniu odpowiednich metod i narzędzi. Identyfikacja nieliniowych zależności, sieciowych sprzężeń, synergii, efektów kumulacyjnych i rykoszetowych konstytutywnych dla systemu ,technika” wymaga przekroczenia granic dyscyplinarnej izolacji dotychczasowych ekspertyz. Chodzi o systematyczną, możliwie pełną i wszechstronną identyfikację społecznie relewantnych skutków określonych technologii na możliwie wielu płaszczyznach: gospodarki, polityki, procesów społecznych, prawa, ekologii itp. oraz wzajemnych zależności między nimi;

4) założenie, że właściwym sposobem pozyskiwania potrzebnej wiedzy jest realizowanie szeroko zakrojonych tematycznych projektów badawczych w odpowiednio dobranych interdyscyplinarnych zespołach złożonych z wysokiej klasy specjalistów biegle

\footnotetext{
${ }^{4}$ Por. A. Grunwald, Technikfolgenabschätzung. Eine Einführung, Edition Sigma, Berlin 2002, s. 126.
} 
posługujących się nowoczesnymi metodami właściwymi dla ich dyscyplin naukowych. Zakłada się, że interdyscyplinarna synteza danych, pochodzących z różnych dziedzin nauki (nauki przyrodnicze, nauki techniczne, psychologia, socjologia, ekonomia, historia czy filozofia), uzyskanych w odmiennych, wzajemnie niekompatybilnych procedurach i wyrażonych w odmiennych jednostkach, jest zasadniczo możliwa;

5) założenie o prognostycznym ukierunkowaniu oceny technologii. Centralnym zadaniem oceny technologii jest wczesne rozpoznanie szans i zagrożeń związanych z rozwojem i upowszechnianiem określonych technologii przy stosunkowo niewielkim zainteresowaniu genezą techniki, warunkami jej powstawania, celami technicyzacji, warunkami jej sukcesu ekonomicznego, zachowaniami użytkowników czy ogólnymi kulturowospołecznymi warunkami ramowymi implementacji danej technologii. Zakłada się więc, że wiedza o tym, jak będzie wyglądał rozwój naukowo-techniczny w przyszłości i jakie będą odległe skutki dzisiejszych decyzji, jest zasadniczo dostępna już dzisiaj.

Podczas 40 lat doświadczeń koncepcja klasyczna ujawniła wiele słabych stron, które w różny sposób korygowano i uzupełniano nowymi rozwiązaniami, co sprawiło, że ocena technologii przeszła interesującą ewolucję. Pomimo upływu czasu i pojawienia się konkurencyjnych programów oceny technologii koncepcja klasyczna ma nadal wielu zwolenników. Zachowano zwłaszcza podporządkowanie wartościowania celom politycznodoradczym oraz jego systemowy i ekspercki charakter. Program uzupełniono wątkami partycypacyjnymi w celu poprawy bazy informacyjnej o wiedzę specyficzną, sytuacyjną, lokalną oraz dla lepszej legitymizacji tego typu doradztwa, a także z zamiarem zapewnienia mu większego społecznego rezonansu.

Jest oczywiste, że do metodologicznej charakterystyki tak zaprogramowanych badań problemowych nie wystarczają kryteria systematyzacyjne tradycyjnej metodologii nauk służące do różnicowania dyscyplin i czynności klasyfikacyjnych, takie jak przedmiot, aspekt, metoda i cel. Dzieje się tak przede wszystkim ze względu na przekrojowy (multi-, trans- i interdyscyplinarny) profil badań oraz ze względu na to, że zadania badawcze nie są sformułowane w kategoriach wewnątrznaukowych, lecz jako społeczne oczekiwania wobec nauki. Obecnie istnieje na obszarze oceny technologii wiele odmiennych orientacji, rozwiązań instytucjonalizacyjnych i stylów prowadzenia badań. Jednomyślności nie ma nawet co do tego, co dokładnie powinno być przedmiotem badań, w jakim aspekcie, jaki stopień ścisłości i jaka wartość rezultatów powinny być wymagane ani też jaka jest ostateczna społeczna finalizacja takich badań. Formułowane definicje mają przeważnie mglisty i ogólnikowy charakter. Jeśli chodzi o cele oceny technologii, to istnieje wiele możliwych scenariuszy społecznej finalizacji:

- polityczne doradztwo decyzyjne na potrzeby polityki technologicznej, innowacyjnej i szeroko rozumianej polityki gospodarczej;

- permanentny monitoring błędów i wczesne ostrzeganie - ocena technologii musi zdążyć, zanim stopień upowszechnienia, poczynione inwestycje, zawarte umowy itd. ograniczą kompetencje decyzyjne w zakresie wyboru określonych opcji technologicznych;

- wczesne rozpoznanie potencjalnych konfliktów społecznych, których źródłem jest polityka technologiczna, zapobieganie i przeciwdziałanie tym konfliktom oraz ich łagodzenie (np. przez działania kompensacyjne), jeśli wystąpią; 
- dostarczanie społeczeństwu elementarnej wiedzy o technologiach i jej skutkach (cele edukacyjne), a dzięki temu stwarzanie społeczeństwu warunków do odpowiedzialnego użytkowania tych technologii 5 .

Jako przedmiot oceny technologii wskazuje się zazwyczaj skutki rozwoju i upowszechniania określonych technologii, przy czym zarówno pojęcie „technologia”, jak i samo pojęcie „skutki” nie są dokładnie wyjaśniane. Intuicyjnie pod pojęciem „technologia" rozumie się coś więcej niż tylko określoną wiedzę operacyjną typu know-how (np. jak spowodować syntezę termojądrową lub jak sklonować owcę) i coś więcej niż tylko odpowiednie narzędzia, środki, infrastruktury i wytwory (artefakty). Szeroko rozpowszechniona jest bowiem świadomość przekrojowości i systemowego charakteru techniki jako względnie autonomicznej całości, w której w różny sposób i na różnych płaszczyznach wzajemnie sprzężone i przenikające się elementy transformująco oddziałują na „otoczenie” (przyrodnicze, społeczne etc.). Po pierwsze, określone technologie, których skutki bierze się jako przedmiot badania, nie stanowią w rzeczywistości jakichś wyizolowanych, odrębnych struktur, ale pewien mniej lub bardziej arbitralny wycinek rzeczywistości. Tym, co przesądza o sposobie „wykadrowania” określonego pola problemowego do szczegółowego badania, nie są kryteria przedmiotowe. O tym, które formy praktyki technicznej są bardziej, a które mniej problematyczne z punktu widzenia społecznego czy politycznego, decydują w praktyce różne kryteria „zewnętrzne”: potencjalne konflikty interesów, widmo globalnej i nieodwracalnej katastrofy ludzkości, niesprawiedliwa dystrybucja szans i ryzyk i inne. Wszystkie te kryteria mają charakter bardzo ogólnie orientujący, w praktyce przedmiot oceny technologii jest zazwyczaj determinowany przez społeczną percepcję problemu.

Również pojęcie skutków w odniesieniu do technologii jest wysoce niejednoznaczne. Często o skutkach technologii mówi się tak, jak gdyby pojęcie skutku było pojęciem empirycznym. Tymczasem pojęcie skutku jest wielowarstwowym konstruktem interpretacyjnym służącym do przyczynowego powiązania następujących po sobie stanów jakiegoś układu. Za skutek masowego stosowania herbicydów w rolnictwie można uznać: odwracalne lub nieodwracalne zmiany w biocenozie użytków rolnych, straty jednych rolników i zyski innych, niezadowolenie konsumentów z chemicznego skażenia żywności, wzrost zachorowań na nowotwory układu pokarmowego, konflikty społeczne, naruszenie zasad zrównoważonego rozwoju, spadek zaufania do regulacyjnej funkcji państwa, wzrost zainteresowania bioetyką itd. Nie jest oczywiście ani możliwa, ani konieczna pełna inwentaryzacja wszystkich skutków określonej technologii rozumianej jako pewien ogół praktyk. Z konieczności pewnym skutkom przypisuje się większe znaczenie niż innym, wiele skutków i ich typów zupełnie wyłącza się poza obszar zainteresowania, a odpowiednie kryteria oceny istotności określonych aspektów eksplikuje się lub nie. Na wstępie każdego projektu trzeba możliwie jasno określić, co jest interesujące, a co mniej. Trzeba się zdecydować, od którego momentu czynniki albo przestają być istotne dla oceny i można je pominąć, albo brakuje czasu, wiedzy lub środków finansowych - i wtedy z konieczności trzeba je pominąć.

Pokrewne tematycznie projekty z obszaru oceny technologii zawsze bardzo różnią się od siebie na płaszczyźnie przedmiotu badania pod względem zakresu, zasięgu i głębi analiz. Jakie obszary techniki poddać badaniu? Z jakimi alternatywnymi wariantami je porównywać? Czy wchodzi w grę całkowita rezygnacja z danej technologii? Jakie skutki

\footnotetext{
${ }^{5}$ Por. ibidem, s. 54-67.
} 
uwzględniać w ocenie: środowiskowe, ekonomiczne, społeczne, zdrowotne, prawne, techniczne, polityczne, kulturowe czy jeszcze inne? Jaki zasięg czasoprzestrzenny skutków można uznać za istotny (horyzont czasowy 10 lat, 25 lat, 50 lat czy więcej)? To przykładowe pytania, od których rozstrzygnięcia zależy w konkretnym przypadku sposób zogniskowania badań. Ponieważ każde z tych pytań cechuje spory zakres zmienności odpowiedzi, jest mało prawdopodobne, aby w dokumentacjach z obszaru oceny technologii znalazły się na świecie dwa opracowania o podobnie zdefiniowanym przedmiocie. Istotnym aspektem w ocenie technologii, który stanowi integralną część większości projektów i który można uznać za ,wspólny mianownik” i obowiązujący standard, jest badanie rozkładu (dystrybucji) skutków na wyróżnione grupy interesariuszy. Na tym jednak kończą się podobieństwa między opracowaniami, na pytanie bowiem, czyje interesy uwzględniać, a czyje pomijać w analizie dystrybucyjnej, udzielane są każdorazowo inne odpowiedzi.

Jeszcze trudniejsza jest jednak charakterystyka oceny technologii pod kątem metody, ponieważ nie istnieją ani specyficzne metody swoiste dla oceny technologii i stosowane tylko na tym obszarze, ani w warunkach pluralizmu podejść nie udało się rozwinąć jednolitego wzornictwa metodycznego typowego dla większości ekspertyz z obszaru oceny technologii. W konkretnym wypadku dobór metod zależy w dużej mierze od definicji przedmiotu badania i sposobu wyznaczenia jego zakresu, zasięgu i głębi. Nie bez znaczenia jest też określenie, z jakich zasobów wiedzy naukowej (z pomocy jakich dyscyplin) należy skorzystać.

Kolejną kwestią wymagającą wyjaśnienia na etapie programowania metodyki badań, od której zależy dobór i hierarchizacja metod wykorzystywanych w ramach konkretnego projektu, jest oczekiwana pewność rezultatów. Pewność poznania tylko częściowo zależy od właściwego doboru i właściwego stosowania metod. Główną determinantą pewności i niepewności twierdzeń w ocenie technologii jest bowiem specyficzny charakter przedmiotu. Ponieważ przedmiotem oceny są najczęściej nowe technologie, nauka nie dysponuje zazwyczaj danymi empirycznymi pozwalającymi w pewny sposób formułować naukowych twierdzeń o wpływie, jaki określona technologia wywrze na przykład na gospodarkę, zatrudnienie, zdrowie, bezpieczeństwo, więzi społeczne czy środowisko, jeśli zostanie masowo upowszechniona. Z braku danych doświadczalnych pozostaje korzystanie z wnioskowań analogicznych lub metod ekstrapolacyjnych, bazujących na założeniu, że między określonymi technologiami istnieją podobieństwa strukturalne i funkcjonalne, które usprawiedliwiają formułowanie twierdzeń o nieznanych skutkach rozwoju i upowszechniania jednej technologii na podstawie doświadczeń we wdrażaniu innej technologii. O nieuchronnej zawodności takich ekstrapolacji świadczą jednak niepowodzenia naukowych prognoz skutków rozwoju i upowszechniania Internetu formułowanych w latach dziewięćdziesiątych $\mathrm{XX}$ w. na podstawie doświadczeń $\mathrm{z}$ przełomu lat pięćdziesiątych i sześćdziesiątych XX w. związanych $\mathrm{z}$ rozwojem i umasowieniem telewizji. Sytuację inherentnej niepewności twierdzeń w ocenie technologii dobitnie oddaje znany aforyzm Marka Twaina: „Prognozowanie jest trudne - szczególnie gdy odnosi się do przyszłości!”. Naukowe twierdzenia o przyszłych skutkach dzisiejszych decyzji związanych z upowszechnianiem innowacyjnych rozwiązań mogą mieć wyłącznie charakter hipotetyczny, i to nie tylko ze względu na to, że twierdzenia te rzeczywiście odnoszą się do przyszłości, ale także dlatego, że współczesny systemowy charakter techniki odbiera człowiekowi bezpowrotnie pewność rezultatów działania. Od działania na chybił trafił zawsze jednak lepsze są twierdzenia prawdopodobne, zwłaszcza jeśli można je przekonująco uzasadnić. 
Jak widać, w ocenie technologii obok treściowej identyfikacji skutków trzeba również ustalić, na ile czynnik „niepewność skutków” danej technologii jest istotny dla jej oceny. Intuicyjnie wiadomo, że prawdopodobieństwo skutków jest zmienną wpływającą na ocenę działania. Jeżeli mamy wybór między dwiema opcjami zaryzykowania empirycznie tego samego stanu rzeczy: ,zginą ludzie”, z tą różnicą, że w wypadku pierwszej opcji ludzie zginą na pewno, a przy drugiej ofiary są możliwe, ale mało prawdopodobne, wówczas korzystniejsza jest opcja druga, pod warunkiem że jej realizacji nie uniemożliwiają inne poważniejsze względy. Skoro więc nie tylko rodzaj i dystrybucja skutków, ale także prawdopodobieństwo ich wystąpienia są czynnikami wpływającymi na ocenę danej technologii, nasuwa się pytanie o współzależność funkcjonalną między oboma czynnikami: czynnikiem jakościowo-ilościowym (skutki i ich dystrybucja) a czynnikiem czysto ilościowym (prawdopodobieństwo wystąpienia).

Co wynika z tej współzależności dla konkretnych rezultatów oceny? Jeżeli mamy wybór między dwiema opcjami zrealizowania empirycznie tego samego celu (stanu) z tą różnicą, że w wypadku pierwszej opcji bardzo prawdopodobne są minimalne szkody zdrowotne ludności, a przy drugiej mało prawdopodobne są poważne szkody zdrowotne tej samej ludności, a niezrealizowaniu owego celu sprzeciwiają się inne poważne względy, wówczas znaczenia nabierają pytania:

- jak małe musi być prawdopodobieństwo poważnych szkód i jak duże musi być prawdopodobieństwo owych minimalnych szkód, aby pierwsza opcja stała się „korzystniejsza”;

- jak małe muszą być owe minimalne szkody, aby mimo ich dużego prawdopodobieństwa opcja pierwsza przeważyła etc. Innymi słowy, chodzi o kwestię porównywalności czynników jakościowych (a raczej: jakościowoilościowych) i czynników ilościowych, która tradycyjnie stanowi przedmiot dociekań na gruncie analizy ryzyka.

Jak pokazano, ocena technologii łączy wiele odmiennych podejść, aspektów i metod. Cechuje się w tym względzie tak dużą zmiennością, że ogólna charakterystyka metodologiczna w tradycyjnych kategoriach nie jest możliwa. Dlatego do metodologicznej charakterystyki oceny technologii bardziej od klasycznego modelu przedmiotu, aspektu, metody i celu nadaje się pojęcie paradygmatu, które wprowadził Thomas S. Kuhn na określenie samoświadomości nauki obejmujące następujące elementy strukturalne: definicję problemów, język i formułowanie pojęć, modele myślenia i kryteria jakościowe ${ }^{6}$. Te wewnętrzne „identyfikatory” są ze sobą przyczynowo ściśle powiązane. Jeśli chodzi o specyficzne modele myślenia, to jedną $\mathrm{z}$ głównych cech rozpoznawczych oceny technologii jest „orientacja na współzależności”. Na przykład podstawę oceny bezpieczeństwa energetycznego stanowią - obok analiz dynamiki popytu, inwentaryzacji zainstalowanych obecnych i przyszłych potencjałów produkcyjnych oraz możliwości importu energii - również analizy współzależności między energetyką a innymi sektorami gospodarki: transportem, budownictwem i mieszkalnictwem czy rolnictwem pod kątem optymalizacji wtórnego i tercjarnego spożycia energii nieuwzględnianego w standardowych bilansach energetycznych.

Ocenę technologii charakteryzuje zróżnicowana wewnętrzna struktura problemowa wymagająca ciągłego i złożonego procesu różnie ukierunkowanej transformacji wiedzy.

\footnotetext{
${ }^{6}$ Por. T.S. Kuhn, Struktura rewolucji naukowych, Wydawnictwo Naukowe PWN, Warszawa 1963.
} 
$\mathrm{Na}$ tę strukturę problemową składają się między innymi problemy z identyfikacją zależności przyczynowo-skutkowych, problemy kognitywne związane z ograniczeniami poznawczymi, problemy związane z kosztami czy kwestia intersubiektywności rozstrzygnięć o charakterze normatywnym (preferencje, wartościowania, akceptacje i awersje etc.). Na te problemy dodatkowo nakładają się zagadnienia złożoności oraz przypadkowości badanych układów. Obszar przedmiotowy oceny technologii jest determinowany $\mathrm{z}$ jednej strony przez naturę i strukturę badanej rzeczywistości (realne sprzężenia w obrębie badanych układów), z drugiej przez potrzeby i wymagania poznawcze (wirtualne sprzężenia w obrębie wiedzy teoretycznej). Te wzajemne dwupłaszczyznowe zależności umożliwiają formułowanie twierdzeń mających wyłącznie charakter zdań warunkowych typu ,jeżeli..., to wtedy...”. Wymagają zaś odejścia od myślenia „liniowego” sprowadzającego wszystko do prostych, jednoczynnikowo uwarunkowanych zależności, w kierunku myślenia „sieciowego” i systemowego. Struktury sieciowe są w ocenie technologii zarazem środkiem i rezultatem poznania. Procesy poznawcze w ocenie technologii mają charakter zespołowy i sieciową strukturę organizacyjną. Ukierunkowanie i sposób zogniskowania konkretnych projektów zależą w praktyce w dużej mierze od doboru zespołu badawczego oraz zewnętrznych afiliacji poszczególnych członków. Duży wpływ na strukturę i przebieg konkretnego procesu badawczego ma „zaplecze ideowe” członków - ich horyzonty naukowe, kultura metodologiczna, nawyki myślowe, otwartość umysłu, etos naukowca itp.

Umiejętność adekwatnego rozwiązywania niezwykle złożonych inter- i transdyscyplinarnych problemów towarzyszących ocenie technologii zależy od zdolności do inteligentnego radzenia sobie ze złożonością. Filarami tej zdolności są znajomość naukowych sposobów przekształcania rzeczywistych złożoności w złożoności nadające się do systematycznego naukowego badania doświadczenie w ich stosowaniu oraz świadomość ograniczeń i naukowej wartości poszczególnych czynności. Sposoby upraszczania złożoności polegają - ogólnie mówiąc - na selektywnym teoretycznym odwzorowaniu wyizolowanych zależności uznanych za konstytutywne oraz na analizie ich przebiegów w określonych układach odniesienia. Do tego celu wykorzystuje się rozmaite metody strukturalizacyjne, określa wartości krańcowe oraz stosuje różne sposoby linearyzacji danych.

Na podstawową charakterystykę metodologiczną oceny technologii składają się następujące wymogi teoretyczne:

- baza kognitywna (zasoby wiedzy) wykracza poza granice dyscyplin, ma charakter integracyjny i nie jest strukturalizowana w odniesieniu do obszaru przedmiotowego;

- rzeczywisty obszar przedmiotowy i naukowy oraz wirtualny przedmiot badań są niezwykle złożone, ale nie ma żadnej jednoznacznej relacji między tymi płaszczyznami;

- złożone struktury obszaru przedmiotowego wymagają teoretycznie ugruntowanej transformacji w adekwatne naukowe metastruktury nadające się do dalszego odpowiedniego opracowania;

- struktury oparte na wewnętrznych sprzężeniach zarówno na poziomie procesowym, jak i na poziomie zasobów wiedzy, stanowiące teoretyczne „rusztowanie" systemu wiedzy, będącego naukową podstawą oceny technologii, wymagają co prawda specjalistycznej dyscyplinarnej wiedzy, nie jest ona jednak warunkiem wystarczającym do właściwego systematycznego wykonania powie- 
rzonych zadań. Do tego potrzebne są kompetencje interdyscyplinarne i wysoka świadomość metodologiczna. W tym sensie stan rozwoju metod na obszarze oceny technologii można potraktować jako wyraz względnego metodologicznego usamodzielniania się oceny technologii jako specjalności naukowej ${ }^{7}$.

Istnieje wiele czynników różnicujących dotychczasowe ekspertyzy z obszaru oceny technologii. Krytyka klasycznej koncepcji oceny technologii wyłoniła podejścia, które programowo chcą uniknąć jej deficytów. Reprezentowane obecnie podejścia i warianty metodyczne są tak niejednorodne, że w ogóle coraz trudniej dziś mówić jeszcze ogólnie o ocenie technologii. Głównymi kryteriami różnicującymi istniejące rozwiązania metodologiczno-organizacyjne są:

1) stosunek do normatywności;

2) cel oceny;

3) przedmiot, zakres, zasięg oceny;

4) adresat i forma instytucjonalizacji

5) perspektywa, aspekt oceny;

6) struktura metodyczna, wzornictwo projektu (Assessment Design);

7) ,punkt wejścia” treści aksjonormatywnych, prymat w ustalaniu ram normatywnych.

\section{NAJPOPULARNIEJSZE METODY WYKORZYSTYWANE W OCENIE TECHNOLOGII}

Na podstawie charakterystyki zawartej w poprzedniej części można zrekonstruować ogólny wzorzec proceduralny oceny technologii, na który składają się następujące etapy postępowania badawczego:

- identyfikacja problemu (źródła kontrowersji) i wybór perspektywy oceny (relewantne wymiary skutków i płaszczyzny odniesienia: bezpieczeństwo, zdrowie i życie ludzi, skutki środowiskowe, gospodarcze, skutki dla jednostki i współżycia społecznego, skutki kulturowe etc., zasięg czasoprzestrzenny oceny);

- odpowiedni dobór metod i określenie szczegółowego wzornictwa projektu;

- identyfikacja skutków w poszczególnych wymiarach (obszarach), szacowanie prawdopodobieństwa ich wystąpienia i ewentualnie analiza dystrybucji skutków;

- teoretyczna „obróbka” uzyskanego materiału empirycznego i formułowanie ocen cząstkowych (w poszczególnych wymiarach) oraz

- całościowa ocena technologii. W niektórych opracowaniach dokonuje się ponadto porównania oceny danej technologii z ocenami alternatywnych, konkurujących z nią wariantów i opcji decyzyjnych.

Omawiając kwestie metod wykorzystywanych w ocenie technologii, kryteriów ich doboru i metodologicznego wzornictwa konkretnych projektów, należy poczynić na wstępie kilka istotnych zastrzeżeń. Po pierwsze, świadomość metodologiczna w praktyce oceny technologii jest różna, w większości opracowań daje się zaobserwować pewna negatywna

\footnotetext{
${ }^{7}$ Por. szerzej na ten temat: V. Zimmermann, Methodenprobleme des Technology Assessment. Eine methodologische Analyse, Kernforschungszentrum KfK 5226, Karlsruhe 1993.

${ }^{8}$ Więcej na temat rozwiązań instytucjonalnych na przykładzie Niemiec zob. K. Michalski, Ewaluacja techniki (Technology Assessment) w Niemczech. Główne instytucje i koncepcje, ,Zeszyty Naukowe Politechniki Rzeszowskiej. Ekonomia i Nauki Humanistyczne" 14/219 (2004), s. 61-122.
} 
tendencja: zainteresowania metodologiczne ustępują często presji pragmatycznej. Bardzo często środek ciężkości jest przesunięty z polityki jakości na politykę wydajności, wykonawcy ekspertyz stosunkowo rzadko zamieszczają wykazy i charakterystyki wykorzystanych metod, a jeszcze rzadziej dokonują oceny ich adekwatności i wartości uzyskanych dzięki nim rezultatów. W konsekwencji w toku 40 lat rozwoju oceny technologii nie zaobserwowano równoległej dyskusji metodologicznej, metody i procedury badawcze udało się tylko nieznacznie udoskonalić, a pochodzące z tego okresu opracowania metodologiczne poświęcone metodom wykorzystywanym w ocenie technologii mają charakter wycinkowy. Po drugie, w ocenie technologii nie obserwuje się też szczególnego nowatorstwa metodycznego, badania problemowe to badania interdyscyplinarne, więc każda relewantna dyscyplina wnosi własne, specyficzne metody i w zasadzie wszystkie stosowane tu procedury są wypróbowanymi metodami nauk przyrodniczych, nauk społecznych, ekonomii, nauk inżynieryjnych itp., tyle że rola i wartość poznawcza tych metod na gruncie oceny technologii różni się od roli i wartości tych metod w na gruncie dyscyplin, z których zostały zapożyczone i mimo popularności, jaką we współczesnej nauce zdobywa idea interdyscyplinarności, ciągle brakuje metod integracyjnych, pozwalających efektywnie wzajemnie transformować wyniki uzyskiwane metodami pochodzącymi z nauk przyrodniczych i wyniki uzyskiwane na przykład metodami socjologicznymi. Jak wspomniano w poprzedniej części, nie udało się również opracować i standaryzować jednej uniwersalnej metodyki takiej pracy naukowej. Mimo to można podjąć próbę prowizorycznej typologii metod i procedur nadających się do wykorzystania w projektach z zakresu oceny technologii na podstawie dotychczasowych opracowań ${ }^{9}$ oraz własnych kwerend w zbiorach raportów z ekspertyz dotychczas zrealizowanych w Stanach Zjednoczonych i Europie.

Pod względem przeznaczenia metody można podzielić na: strukturalizujące (teoria systemów i analiza systemowa, analiza ryzyka, analiza przepływów, analiza oddziaływań, ekobilans, analiza wejście-wyjście, analizy łańcuchów procesowych i inne), pozyskiwania danych (metody oparte na danych pierwotnych oraz metody oparte na danych wtórnych, takie jak kwerendy, analizy dokumentów, wywiady z ekspertami, systemy bazodanowe i inne), heurystyczne (burza mózgów i sesje pomysłowości, matryce morfologiczne, metody synektyczne, wywiady z ekspertami, metody delfickie, metody wpływów krzyżowych i inne), prognostyczne (głównie metody ekstrapolacyjne, modelowanie i metody symulacyjne, metody analogiczne oraz metody scenariuszowe) i ewaluacyjne (wartościowanie socjoetyczne i rachunek utylitarystyczny, analiza użyteczności, analiza kosztówkorzyści, analiza opłacalności, analiza istotności, analiza drzewa wartości, analiza i rekonstrukcja dyskursu, procedury partycypacyjne i inne).

\footnotetext{
${ }^{9}$ Por. A.L. Porter, F. Rossinni, S.R. Carpenter, A.T. Roper, R.W. Larson, J.S. Tiller, A guidebook for technology assessment and impact analysis, North Holland, New York 1980; O. Renn, Methoden und Verfahren der Technikfolgenabschätzung und der Technologiebewertung, [w:] Technik auf dem Prüfstand: Methoden und Maßstäbe der Technologiebewertung, red. E. Münch, O. Renn, T. Roser, Girardet/Gräfelfing (Energiewirtschaft \& Technik), Essen 1982, s. 62-84; A. Grunwald, Technikfolgenabschätzung. Eine Einführung, Edition Sigma, Berlin 2002; T.A. Tran, Review of Methods and Tools Applied in Technology Assessment Literature, [w:] Proceedings Management of Converging Technologies, red. D.F. Kocaoglu, T.R. Anderson, T.U. Daim, Portland International Center for Management of Engineering and Technology, Portland (Oh.) 2007, s. 16511660; T.A. Tran, T.U. Daim, A taxonomic review of methods and tools applied in technology assessment, „Technological Forecasting and Social Change" 75/9 (2008), s. 1396-1405.
} 
Ze względu na rodowód można wyróżnić: metody zorientowane technologicznie (szacowanie ryzyka i metoda wartości granicznych, metoda rekonstrukcji preferencji ujawnionych, metoda analizy preferencji wyrażonych i inne), metody wywodzące się z ekonomii (teorie dobrobytu, teorie wyboru publicznego, analiza marginalna, metody wskaźnikowe wykorzystujące wskaźniki społeczne i inne), metody zorientowane politycznie [teorie wyboru, procedury plebiscytowe, procedury partycypacyjne, takie jak mediacje, publiforum, jury obywatelskie, panel laików, konferencja uzgodnieniowa (konsensualna), publifocus, komórka planowania, warsztaty przyszłości, dyskurs kooperacyjny itp., metoda borykania się, metoda skanowania mieszanego i inne], systematyczne metody bilansowe [analiza kosztów-korzyści, analiza korzyści i ryzyka, metody wieloatrybutowego podejmowania decyzji, modele planistyczne (np. PPBS, Planning, Programming, and Budgeting System) i inne] oraz metody wywodzące się z teorii systemów i analizy systemowej (metody scenariuszowe, analiza współzależności, koncepcje potrzeb podstawowych i inne).

$\mathrm{Z}$ braku miejsca w tym wyszczególnieniu ograniczono się jedynie do wskazania metod przydatnych w projektach z zakresu oceny technologii, bez wgłębiania się w ich indywidualną charakterystykę. Zainteresowani szczegółami znajdą opis poszczególnych metod w przystępnej formie $\mathrm{w}$ innym miejscu ${ }^{10}$. Należy pamiętać o tym, że wyróżnione procedury nie są swoistymi metodami zarezerwowanymi wyłącznie do oceny technologii. Wszystkie zaprezentowane metody - pomimo swoich wad i ograniczeń - stanowią sensowne i wartościowe narzędzia nadające się do wykorzystania w ocenie technologii. Każda z metod ułatwia podejmowanie decyzji i ich społeczne legitymizowanie, pod warunkiem że uzyskane $\mathrm{z}$ ich pomocą rezultaty są właściwie interpretowane, panuje pełna świadomość ich ograniczonej ważności tam, gdzie możliwości obiektywnego, empirycznego badania się wyczerpują i trzeba kierować się subiektywnymi preferencjami i intuicyjnymi szacunkami, gdzie należy zachowywać najwyższą ostrożność, właściwie oddzielać obiektywne treści opisowe od wartościowań, odpowiednio je oznakowywać i podawać warunki ich ważności.

Zarządzając projektami z zakresu oceny technologii i opracowując własne wzornictwo metodyczne, należy również w pełni zdawać sobie sprawę ze specyfiki badań problemowych, w których dobór metod i jakość uzyskanych rezultatów nie zależą od kryteriów stricte naukowych. Gdyby bowiem tak było, najbardziej dolegliwy na gruncie doradztwa politycznego problem przeciwstawnych ekspertyz można byłoby rozwiązać naukową standaryzacją procedur. To jednak nie oznacza, że w ocenie technologii należy akceptować zupełną dowolność. Wręcz przeciwnie, w warunkach panującego pluralizmu i w obliczu społecznej wagi ekspertyz należy jeszcze więcej krytycznej uwagi poświęcać kwestiom metodyki i organizacji poszczególnych procedur, a ocenę jakości uzyskanych rezultatów oceny technologii uzależniać od poziomu świadomości metodologicznej wykonawcy. Dotyczy to zwłaszcza wstępnej, koncepcyjnej fazy badań. Za optymalną koncepcję metodologiczną oceny technologii można uznać szacowanie skutków wykorzystujące wszystkie znane metody nie na zasadzie liniowej i terminalnej (jedna po drugiej), ale na zasadzie rekursywnej (rezultaty każdego kroku mogą wymagać sprawdzenia każdego poprzedniego kroku) i otwartej (zawsze nowa wiedza lub nowe przypuszczenia mogą spowodować podjęcie szacowania skutków na nowo). Dzięki rekursywności i otwartości

${ }^{10}$ Zob. K. Michalski, Przegląd metod i procedur wykorzystywanych w ocenie technologii, „Studia Biura Analiz Sejmowych" 43/3 (2015), s. 55-86. 
procedury można stopniowo udoskonalać i nawet metody prezentacji graficznej tymczasowych rezultatów mogą się stać użytecznymi metodami heurystycznymi pozwalającymi identyfikować nowe, nieuwzględniane dotąd aspekty i otwierającymi nowe perspektywy spojrzenia na badany problem.

Optymalnym połączeniem metodologicznym wydaje się wielomodułowa procedura oceny obejmująca jako pierwszy moduł budowanie strategii zaspokojenia potrzeb opartej na teorii potrzeb podstawowych, następnie inwentaryzację i ocenę poszczególnych wariantów pod kątem skutków społeczno-gospodarczych na podstawie wskaźników społecznych, następnie identyfikację zwrotnych sprzężeń i ewentualnych nieoczekiwanych oddziaływań technologii na sąsiadujące z nią systemy za pomocą modeli interdependencyjnych (analizy współzależności) oraz dokonywanie oceny danej technologii w wybranej procedurze partycypacyjnej na podstawie zbiorów informacji uzyskanych w poprzednich etapach. Proces oceny technologii mogłaby zamykać analiza efektywności kosztowej, która pozwalałaby zoptymalizować każdy wariant decyzyjny pod kątem zarządzania bezpieczeństwem.

Przy budowaniu optymalnej procedury należy jednak pamiętać o tym, że o doborze metod w pierwszej kolejności przesądzają instytucjonalne „,zakorzenienie” określonego wykonawcy projektu oraz profil adresata. Kluczowe znaczenie ma między innymi to, jaką misję realizuje konkretna organizacja zajmująca się projektami z zakresu oceny technologii, czy jest to niezależna instytucja stricte naukowa, czy raczej organ doradczy związany z władzą ustawodawczą, administracją czy konkretnym ugrupowaniem politycznym, jaką wiedzą (zarówno pod względem jakościowym, jak i ilościowym), jakimi zasobami ludzkimi i materialnymi oraz jakimi zestawami metod dysponuje. Czy istnieją jakiekolwiek „luki” (w wiedzy, w zasobach kadrowych etc.)? Kim są adresaci? Jaka jest specyfika badanego problemu i jakie są oczekiwania zamawiającego odnośnie do sposobu ,wykadrowania" tego problemu z szerszego kontekstu? W jakiej fazie politycznego procesu kształtowania danej technologii dokonuje się jej oceny? Czy na tym etapie społeczeństwo sprawuje kontrolę nad rozwojem danej technologii i czy rezultaty oceny wywrą wpływ na ocenianą sytuację? Jaka jest intensywność debaty politycznej i społecznej w badanej kwestii? Jaka jest skala społecznej konfliktowości badanego problemu? Czy w tej sprawie panuje jednomyślność w kręgach ekspertów i jaka jest ewentualnie skala rozbieżności w opiniach uczonych?

Niezależnie od wyboru konkretnych rozwiązań metodycznych sensownym postępowaniem jest wielokrotne przejście odpowiednio zaprogramowanej procedury oceny i zakończenie jej dopiero wtedy, gdy kolejna prezentacja nie da już żadnego nowego poznania.

\section{WYMAGANIA JAKOŚCIOWE STAWIANE EKSPERTYZOM Z OBSZARU OCENY TECHNOLOGII}

Ze względu na pluralizm metod, eksperymentalny charakter i różnorodność stylów uprawiania oceny technologii dotychczasowe próby metodologicznego porządkowania tego obszaru badań stosowanych nie zaowocowały przekonującymi naukowymi klasyfikacjami. Przy obecnym stanie dyskusji metodologicznej opracowanie i wdrożenie jednolitych międzynarodowych standardów metodycznych określających „,warsztat” obowiązujący w ocenie technologii i dziedzinach pokrewnych nie wydaje się możliwe w najbliższej 
przyszłości. Sytuację komplikują bowiem trzy podstawowe problemy metodyczne, z jakimi boryka się ocena technologii:

- trudności w urzeczywistnianiu interdyscyplinarności, związane zwłaszcza $\mathrm{z}$,opanowaniem” i integracją dużych heterogenicznych strumieni danych ${ }^{11}$;

- trudności w urzeczywistnieniu postulowanej neutralności aksjonormatywnej oraz

- trudności związane ze społeczną legitymizacją doradztwa politycznego w warunkach tzw. dylematu ekspertowego ${ }^{12}$.

Wypróbowując różne rozwiązania wymienionych trudności, wypracowano ogólne standardy jakościowe, które można sprowadzić do wymogów proceduralnych, zewnętrznych i wewnętrznych cech związanych z doborem i naborem ekspertów oraz organizacją procesu badawczego, z odpowiednim reżimem metodologicznym oraz z transparentnością i społecznym nadzorem nad całością procesu doradczo-decyzyjnego. Zewnętrznymi cechami rozpoznawczymi każdego dobrego doradztwa naukowego, w tym również ekspertyz z obszaru oceny technologii, są: 1) intersubiektywność, transparentność, przejrzystość procedur; 2) społeczna legitymizacja i autorytet, których podstawą jest niepodważalne znawstwo rzeczy, biegłość i fachowość poparta odpowiednim doświadczeniem oraz 3) całkowita neutralność i bezstronność (polityczna, klasowa, światopoglądowa etc.), brak jakichkolwiek zewnętrznych lojalności i uprzedzeń ${ }^{13}$. W praktyce istnieje jednak spory problem ze wszystkimi trzema postulatami. Intersubiektywność i przejrzystość (1) stają pod znakiem zapytania już przez samo to, że w realiach politycznych całkowicie nieprzejrzysta jest rekrutacja gremiów ekspertowych. Kryteria selekcji mają zbyt często charakter pozamerytoryczny, w większości przypadków o doborze ekspertów decydują osobiste powiązania. Powoływanie konkretnych osób do gremiów doradczych powinno leżeć w gestii nie samych adresatów i beneficjentów ekspertyzy, ale społeczności uczonych (np. komitety Polskiej Akademii Nauk, Narodowe Centrum Nauki, towarzystwa naukowe, uczelnie według rankingów są w stanie uczciwie rekomendować kandydatów, podobnie jak rekrutuje się dzisiaj gremia, które ewaluują uczelnie w ramach działań akredytacyjnych czy recenzują osiągnięcia naukowe w procedurach awansowych). Niestety wielu uczonych w definiowaniu swoich kompetencji i swojego znawstwa zagadnienia (2) wykazuje sporą wielkoduszność. Często postrzega się przynależność do określonych kultur naukowych (dyscyplin społecznie uprzywilejowanych, traktowanych jako nauki wyższej rangi, takich jak choćby fizyka jądrowa, toksykologia środowiskowa czy ekonomia) jako mandat do wydawania kompetentnych naukowych sądów na przykład o wpływie określonych technologii na człowieka i społeczeństwo czy o użyteczności lub dopuszczalności badań nad ludzkimi embrionalnymi komórkami macierzystymi. Do działalności eksperckiej w ramach doradztwa politycznego kwalifikują z jednej strony odpowiednia specjalizacja i odpowiedni dorobek badawczy przynajmniej z niedawnej przeszłości, z drugiej strony odpowiedni poziom kultury metodologicznej, kompetencje interdyscyplinarne,

${ }^{11}$ Szerzej na temat problemów z interdyscyplinarnością i możliwości ich rozwiązywania zob. K. Michalski, Interdyscyplinarność - transdyscyplinarność - multidyscyplinarność. Nowy paradygmat w nauce i badaniach, „Zeszyty Naukowe Politechniki Rzeszowskiej. Ekonomia i Nauki Humanistyczne” 16/235 (2007), s. 83-100.

${ }^{12}$ Szerzej na ten temat zob. K. Michalski, Dylemat ekspertowy w ocenie technologii. Zarys problemu, „Zeszyty Naukowe Politechniki Rzeszowskiej. Ekonomia i Nauki Humanistyczne” 18/282 (2011), s. 123-134.

${ }^{13}$ Por. C.F. Gethmann, Probleme wissenschaftlicher Politikberatung in Deutschland, „Europäische Akademie Bad Neuenahr-Ahrweiler Newsletter" 2006/60, s. 2. 
ogólna orientacja naukoznawcza i świadomość osobliwości innych dyscyplin i typów wiedzy. Ale takich kompetencji nie może ocenić nikt spoza świata nauki, w każdym razie z pewnością nie adresat doradztwa. Postuluje się więc, aby wspólnota uczonych prowadziła odpowiednią certyfikację na potrzeby doradztwa politycznego. Jednak w żadnym kraju nie udało się dotychczas wypracować zadowalających procedur certyfikacyjnych.

Głównym wymogiem jakościowym związanym z reżimem metodologicznym jest konieczność ciągłego udoskonalania metod teoretycznych i eksperymentalnych, miksowania poszczególnych metod oraz równoległej metodologicznej kontroli nad podejmowanymi czynnościami i uzyskiwanymi rezultatami, pozwalającej na bieżącą weryfikację i ocenę wartości wyników uzyskanych różnymi, często wzajemnie niekompatybilnymi metodami. W tym celu stosuje się takie metody jak analiza punkt po punkcie (step-by-step), analiza konwergencyjna czy ekspertyzy zachodzące na siebie. Wypróbowanym i często wykorzystywanym narzędziem do oceny wartości ekspertyzy jest analiza porównawcza w grupie pokrewnych tematycznie, ale niezależnych od siebie opracowań. Metody statystyczne nie pozwalają co prawda poprawiać wadliwych ekspertyz, ale umożliwiają przynajmniej ograniczenie ich wpływu na decyzje polityczne.

Natomiast wymogi związane ze społeczną legitymizacją oceny technologii są obecnie realizowane na dwóch płaszczyznach: w ramach ,polityki reputacyjnej” organizacje eksperckie wdrażają odpowiednie standardy etyczne i wiarygodne procedury ich egzekwowania, a w ramach ,polityki jawności” doradztwo ekspertowe uzupełnia się elementami partycypacyjnymi ${ }^{14}$. W odniesieniu do społecznej wiarygodności uznaje się, że oprócz określonych kompetencji kognitywnych eksperci działający na obszarze oceny technologii powinni odznaczać się wysokim poziomem etycznym i cieszyć nieposzlakowaną moralną reputacją. Tymczasem w naukowym doradztwie politycznym niebezpiecznym zjawiskiem jest utrzymujący się koniunkturalizm i oportunizm ekspertów. W odbiorze społecznym ekspert coraz częściej jest dzisiaj postrzegany nie jako neutralny, bezstronny znawca tematu, ale raczej jako stronniczy, koniunkturalny, a nawet przekupny człowiek interesu operujący naukowymi półprawdami. W sytuacji ekonomicznej zależności, odczuwanej bardziej dotkliwie w warunkach obecnego kryzysu, wierność naukowej prawdzie wymaga od eksperta dużej odporności na rozmaite pokusy. Aktualnie w większości krajów główni aktorzy w ocenie technologii to spółki z ograniczoną odpowiedzialnością podlegające normalnym wahaniom koniunktury i prawom konkurencji. Komercjalizacja oceny technologii sprawia, że eksperci często świadomie „zbaczają z właściwego kursu” i dostarczają naukowych potwierdzeń zgodnych z oczekiwaniami zamawiającego.

Ponadto ekspert, w nie mniejszym stopniu niż przeciętny obywatel, ma określone sympatie i antypatie polityczne, określone przekonania światopoglądowe, a nierzadko nawet odchylenia ideologiczne. Zdarza się także, że lojalność wobec określonych ideologii czy sił politycznych potrafi tak zaślepić uczonych - w gruncie rzeczy ludzi rozumu że są gotowi wykorzystywać swój prestiż do publicznego propagowania określonych politycznych idei. Coraz częściej popełnianym przez ekspertów przewinieniem jest również dostosowywanie się do oczekiwań opinii publicznej. Szczególnie wyraziście widać ten trend na obszarze oceny ryzyka - wiarygodność fachowca w oczach opinii publicznej

\footnotetext{
${ }^{14}$ Szerzej na temat modeli partycypacyjnych w ocenie technologii i wybranych metod partycypacyjnych zob. K. Michalski, Uczestnictwo obywateli w publicznych procesach decyzyjnych jako forma aktywności obywatelskiej na przykładzie partycypacyjnej oceny technologii (pTA), [w:] Aktywność obywatelska we wspótczesnym społeczeństwie demokratycznym, red. R. Klamut, H. Sommer, K. Michalski, Seiton, Kraków 2010, s. 59-110.
} 
wzrasta tym bardziej, im wyżej ocenia on jakieś ryzyko. Ci sami uczeni, którzy w fachowej dyskusji naukowej krytycznie i samokrytycznie sprawdzają każde twierdzenie pod kątem prawomocności, są gotowi do ustępstw wobec „ducha czasu”, gdy tylko znajdą się w centrum uwagi mediów.

Metodologiczna obiektywność wymaga jednak, aby żadne pozanaukowe czynniki nie wpływały na zasady i rezultaty postępowania badawczego. Na naukowcu ciąży szczególny obowiązek: musi zawsze jasno i jednoznacznie zadeklarować, kiedy wypowiada się jako naukowiec, a kiedy jako obywatel zaangażowany politycznie. Uczciwy, świadomy swojej odpowiedzialności i godny zaufania ekspert nawet pod presją oczekiwań ze strony polityki czy opinii publicznej nie pozostawi cienia wątpliwości co do tego, co w świetle naukowych standardów można potraktować jako „naukowo uzasadnione”, a co według jego własnej wiedzy wydaje się prawdopodobne, co możliwe, a co całkowicie nieprawdopodobne.

\section{PODSUMOWANIE}

Ocena technologii jako forma inter- i transdyscyplinarnej działalności naukowodoradczej realizowanej na potrzeby nowoczesnej polityki technologicznej mimo ponad czterdziestoletniej historii nie rozwinęła dotąd pełnej metodologicznej samoświadomości i nie dopracowała się jeszcze odrębnej metodologii. Ze względu na inter- i transdyscyplinarny charakter ocena technologii wykazuje tak duże wewnętrzne zróżnicowanie (wielość podejść i różnorodność stylów, zmienność form instytucjonalizacji i finalizacji itp.), że wymyka się próbom charakterystyki metodologicznej w kategoriach klasycznej metodologii nauk i dopuszcza jedynie przybliżoną charakterystykę paradygmatyczną uwzględniającą sposób definiowania problemów, osobliwości języka, dominujące modele myślenia, metody i kryteria jakościowe. Paradygmat wyznaczyła klasyczna koncepcja oceny technologii, opracowana i realizowana w latach 1972-1995 przez Biuro Oceny Technologii przy Kongresie Stanów Zjednoczonych i do dzisiaj jest ona modyfikowana i udoskonalana na świecie.

Ze względu na profil naukowo-doradczy ocena technologii jest pod względem metodycznym rodzajem międzynarodowego laboratorium, w którym różne kultury ekspertowe wypróbowują różne zestawy metod w celu naukowego opanowania złożoności interakcji określonych systemów technicznych z różnie definiowanym otoczeniem oraz wymieniają się doświadczeniami. To wymaga odpowiedniego doboru solidnej, ugruntowanej wiedzy z różnych dyscyplin i specjalności naukowych oraz odpowiedniego zintegrowania tych heterogenicznych elementów. Dlatego kluczową rolę w repertuarze metodycznym oceny technologii odgrywają metody organizacji i syntezy wiedzy, służące do wzajemnego powiązania, zrównoważenia i systematyzacji wiedzy uzyskanej różnymi metodami w odległych od siebie obszarach nauki i wyrażonej w obcych sobie językach. Dużego znaczenia w projektach z obszaru oceny technologii nabierają metody strukturalizujące i integracyjne wywodzące się z tradycji ogólnej teorii systemów.

Ponieważ jednak warunki zawarte w społecznym zamówieniu na ekspertyzy z obszaru oceny technologii i wynikające $\mathrm{z}$ nich wymogi jakościowe są częściowo przeciwstawne, nie udało się dotąd nikomu zrealizować w pełni klasycznego programu wczesnego, naukowo ugruntowanego i zreflektowanego, interdyscyplinarnego, komprehensywnego, aksjonormatywnie neutralnego i społecznie wiarygodnego oszacowania skutków danej tech- 
nologii. To jednak nie pozbawia oceny technologii doniosłej funkcji orientującej i racjonalizującej z punktu widzenia polityki technologicznej.

\section{LITERATURA}

[1] Gethmann C.F., Probleme wissenschaftlicher Politikberatung in Deutschland, „Europäische Akademie Bad Neuenahr-Ahrweiler Newsletter" 2006/60, s. 1-3.

[2] Gloede F., Rationalisierung oder reflexive Verwissenschaftlichung? Zur Debatte um die Funktionen von Technikfolgen-Abschätzung für Technikpolitik, [w:] Technikfolgen-Abschätzung als Technikforschung und Politikberatung, red. Th. Petermann, Frankfurt am Main 1991, s. 299328.

[3] Grunwald A., Technikfolgenabschätzung. Eine Einführung, Edition Sigma, Berlin 2001.

[4] Kuhn T.S., Struktura rewolucji naukowych, Wydawnictwo Naukowe PWN, Warszawa 1963.

[5] Michalski K., Ewaluacja techniki (Technology Assessment) w Niemczech. Główne instytucje i koncepcje, ,Zeszyty Naukowe Politechniki Rzeszowskiej. Ekonomia i Nauki Humanistyczne” 14/219 (2004), s. 61-122.

[6] Michalski K., Interdyscyplinarność - transdyscyplinarność - multidyscyplinarność. Nowy paradygmat w nauce i badaniach, ,Zeszyty Naukowe Politechniki Rzeszowskiej. Ekonomia i Nauki Humanistyczne" 16/235 (2007), s. 83-100.

[7] Michalski K., Uczestnictwo obywateli w publicznych procesach decyzyjnych jako forma aktywności obywatelskiej na przykładzie partycypacyjnej oceny technologii (pTA), [w:] Aktywność obywatelska we wspótczesnym spoteczeństwie demokratycznym, red. R. Klamut, H. Sommer, K. Michalski, Seiton, Kraków 2010, s. 59-110.

[8] Michalski K., Dylemat ekspertowy w ocenie technologii. Zarys problemu, ,Zeszyty Naukowe Politechniki Rzeszowskiej. Ekonomia i Nauki Humanistyczne” 18/282 (2011), s. 123-134.

[9] Michalski K., Przeglad metod i procedur wykorzystywanych $w$ ocenie technologii, „Studia Biura Analiz Sejmowych" 43/3(2015), s. 55-86.

[10] Porter A.L., Rossinni F., Carpenter S.R., Roper A.T., Larson R.W., Tiller J.S., A guidebook for technology assessment and impact analysis, North Holland, New York 1980.

[11] Renn O., Methoden und Verfahren der Technikfolgenabschätzung und der Technologiebewertung, [w:] Technik auf dem Prüfstand: Methoden und Maßstäbe der Technologiebewertung, red. E. Münch, O. Renn, T. Roser, Girardet/Gräfelfing (Energiewirtschaft \& Technik), Essen 1982, s. 62-84.

[12] Tran T.A., Review of Methods and Tools Applied in Technology Assessment Literature, [w:] Proceedings Management of Converging Technologies, red. D.F. Kocaoglu, T.R. Anderson, T.U. Daim, Portland International Center for Management of Engineering and Technology, Portland (Oh.) 2007, s. 1651-1660.

[13] Tran T.A., Daim T.U., A taxonomic review of methods and tools applied in technology assessment, ,Technological Forecasting and Social Change” 75/9 (2008), s. 1396-1405.

[14] Zimmermann V., Methodenprobleme des Technology Assessment. Eine methodologische Analyse, Kernforschungszentrum KfK 5226, Karlsruhe 1993.

\section{METHODOLOGICAL PROBLEMS IN MANAGEMENT OF TECHNOLOGY ASSESSMENT PROJECTS}

The article describes main methodological problems connected with realization of expertise in the field of technology assessment. Technology assessment is internally very diverse field of problem research lying at the interface of science, politics, technology and society, which based on current knowledge dispersed in the various scientific disciplines try to identify possible paths of technological development, to predict future effects and impacts of (political) decisions about specific paths for the individuals and society, the economy and 
the environment, national security and the state's position in the global technology race and to evaluate these consequences in terms of values accepted by society. Management of research projects with such aspirations requires extensive methodological competences and experiences. Consisting of four parts, the article is intended for readers with a basic understanding of the theory of science and the general methodology of science. The first part discusses the importance of technology assessment for the modern technology and innovation policy. The next part contains a brief description of the general methodological characteristics of technology assessment as interdisciplinary and transdisciplinary research about determinants and impacts of technology development and dissemination. The third part presents the most popular methods and procedures which are suitable for use in technology assessment. In the fourth part, the author compiles the main qualitative requirements which are faced to expertise in the field of technology assessment. The main focus is placed on classical concept of technology assessment realized by Office of Technology Assessment by United States Congress in 1972-1995. Based on analysis of theoretical assumptions of classical concept of technology assessment, the methodological profile of technology assessment and the critical moments of this paradigm of problem oriented research were defined and identified. In conclusion, a universal procedural model of technology assessment as a combination of several proven methods was proposed.

Keywords: project management, technology assessment, impact assessment, methodology of sciences, scientific political advice, quality standards of expertise

DOI: 10.7862/rz.2015.mmr.39

Tekst złożono w redakcji: wrzesień 2015

Przyjęto do druku: październik 2015 